\title{
THE PREAMBLE OF THE ICSID CONVENTION
}

\author{
Julien Fouret and Luiza Saldanha Pena Costa
}

The Contracting States

Considering the need for international cooperation for economic development, and the role of private international investment therein;

Bearing in mind the possibility that from time to time disputes may arise in connection with such investment between Contracting States and nationals of other Contracting States;

Recognizing that while such disputes would usually be subject to national legal processes, international methods of settlement may be appropriate in certain cases;

Attaching particular importance to the availability of facilities for international conciliation or arbitration to which Contracting States and nationals of other Contracting States may submit such disputes if they so desire;

Desiring to establish such facilities under the auspices of the International Bank for Reconstruction and Development;

Recognizing that mutual consent by the parties to submit such disputes to conciliation or to arbitration through such facilities constitutes a binding agreement which requires in particular that due consideration be given to any recommendation of conciliators, and that any arbitral award be complied with; and

Declaring that no Contracting State shall by the mere fact of its ratification, acceptance or approval of this Convention and without its consent be deemed to be under any obligation to submit any particular dispute to conciliation or arbitration,

Have agreed as follows:

\section{INTRODUCTION}

0.01 On 18 March 1965, the Executive Directors of the World Bank submitted the text of the Convention on the Settlement of Investment Disputes between States and Nationals of other States (hereinafter, the 'ICSID Convention' or the 'Convention') for

1 The authors wish to thank Morgane Barataud, Bertille Henry and Laila E1 Hakim, who provided an invaluable assistance during the preparation of this commentary. 
the consideration of the member governments of the World Bank, with a view to its signature and ratification.

The Executive Directors drafted an explanatory report accompanying the Convention (hereinafter, the 'Report'), ${ }^{2}$ in which they expressed that they were 'prompted by the desire to strengthen the partnership between countries in the cause of economic development' and that:

The creation of an institution designed to facilitate the settlement of disputes between States and foreign investors [the International Centre for Settlement of Investment Disputes (hereinafter, 'ICSID' or the 'Centre')] can be a major step toward promoting an atmosphere of mutual confidence and thus stimulat $[\mathrm{e}]$ a larger flow of private international capital into those countries which wish[ed] to attract it. ${ }^{3}$

Although the Report sheds light on the aims of the drafters of the Convention, this text is not the only source of guidance for assessing the reasons of its drafting and submission. The Preamble of the ICSID Convention (hereinafter, the 'Preamble') also clearly reveals the main object and purpose of the latter.

As an illustration, this function was described in Mitchell v. Congo, where the tribunal observed that the Preamble 'sets forth a number of basic principles as to its purpose and aims, which imbue the individual provisions of the Convention, including Article $25{ }^{\prime}{ }^{4}$

As explained by its drafters, 'the Preamble contains a general statement of the aims and purposes of the Convention' and is also 'intended to be declaratory of the fundamental norms upon which the specific rules of the Convention are based'. ${ }^{5}$ It further provides for general understandings, which reduce the scope of the Convention. It bestows an explicit explanation of some points that are not specifically defined in the rest of the text, such as, the category of disputes which can be administered by the Centre. ${ }^{6}$

2 History of the ICSID Convention (1970) Vol. I, 12 <https://icsid.worldbank.org/en/Documents/resources/History\%20 of\%20ICSID\%20Convention\%20-\%20VOLUME\%20I.pdf> (accessed 22 October 2018).

3 Report of the Executive Directors on the Convention on the Settlement of Investment Disputes between States and Nationals of Other States, International Bank for Reconstruction and Development (18 March 1965), para. 9 <https://icsid. worldbank.org/en/Documents/resources/ICSID_Conv\%20Reg\%20Rules_EN_2003.pdf> (accessed 22 October 2018).

4 Patrick Mitchell v. The Democratic Republic of Congo, Case No. ARB/99/7, Decision on the Application for Annulment of the Award (9 February 2004), para. 28.

5 History of the ICSID Convention (2009) Vol. II-1, 135 <https://icsid.worldbank.org/en/Documents/resources/ History\%20of\%20ICSID\%20Convention\%20-\%20VOLUME\%20II-1.pdf> (accessed 22 October 2018).

6 ibid. 149. 
0.06 Since the outset of the Convention's implementation, the Preamble has been used for various purposes, for instance, clarifying the notion of consent to arbitration, and narrowing or expanding the jurisdiction of the Centre.

0.07 On that subject matter, the existence of treaty preambles can be traced back to the very first peace treaty in history, negotiated in the thirteenth century BC between Ramses II's pharaonic Egypt and a neighbouring power, known as the Treaty of Kadesh. ${ }^{7}$ Ever since, preambles have been a continuous source of confusion and uncertainty with regards to their specific role in treaty interpretation. ${ }^{8}$

0.08 Nevertheless, Article 31 of the Vienna Convention on the Law of Treaties' (the 'Vienna Convention') explicitly provides that preambles and annexes shall qualify as part of a treaty for the purposes of interpretation. Relying on the preamble is thus encouraged under international law and has also been necessary in the particular case of UK ICSID arbitration, as it has allowed ICSID arbitral tribunals to adapt to situations that were not foreseen and/or addressed by the drafters of the ICSID Convention in its main body.

0.09 In this regard, the role that the Preamble has played in arbitral decisions is remarkable. Parties to arbitral proceedings have been invoking not only the provisions and articles of the ICSID Convention, but also its Preamble, using it as a sort of compass providing evidence of the underlying aims of the drafters of the Convention. Arbitral tribunals have similarly relied on the Preamble to properly interpret articles of the ICSID Convention and to further delineate its scope. Indeed, the Preamble has been cited in dozens of arbitral decisions and arbitrator's opinions.

0.10 Some arbitral tribunals have also gone beyond merely invoking the Preamble as a tool for interpretation, and conferred instead a normative value to its provisions. Thus, the debate upon the normative relevance of the Preamble has become central to the analysis of the ICSID Convention as a whole. Moreover, the relevance of the Preamble for the definitions of key notions contained in the Convention, such as the ones of 'consent to arbitration', of 'investment' and of 'foreign investor', is quite notable, as it seems to have inspired arbitral tribunals in setting, interpreting and clarifying their terminology.

7 J.J. Mark, 'The Battle of Kadesh \& the First Peace Treaty', Ancient History Encyclopedia (18 January 2012) <www.ancient.eu/article/78/> accessed on 22 October 2018.

8 Max H. Hulme, 'Preambles in Treaty Interpretation' (2016) 164 University of Pennsylvania Law Review 1281, 1284.

9 United Nations, Vienna Convention on the Law of Treaties, 23 May 1969, United Nations, Treaty Series, Vol. 1155, 331. 


\section{THE PREAMBLE: FROM AN INTERPRETATIVE TOOL TO A NORMATIVE FUNCTION}

When talking about preambles in general, and in particular about the Preamble, a ques0.11 tion arises in relation to their normative function.

Unlike in the French legal system - where the preamble to the French Constitution is also given a constitutional value since 1971 - the normative function of preambles in international law is subject to controversies. However, whilst the debate as to their legal nature remains, it is widely admitted that their value shall not be neglected, especially when it comes to interpreting the core of a treaty in order to determine the intention of the contracting parties. ${ }^{10}$

As noted above, the Vienna Convention states that Preambles are an integral part of the text of a treaty. ${ }^{11}$ In fact, Article 31 ranks Preambles as a primary resource of interpretation with regards to the treaty by stating the following: 'The context for the purpose of the interpretation of a treaty shall comprise, in addition to the text, including its preamble and annexes'. ${ }^{12}$ In other words, according to the Vienna Convention, preambles are depicted as predominant interpretative tools for determining the purpose of a treaty.

Although the Vienna Convention only came into force in 1980, years after its signature, and after the entry into force of the ICSID Convention in 1966, ICSID tribunals have largely relied on the principles set out therein and considered it to be a codification of customary law ${ }^{13}$ and of general principles of interpretation. ${ }^{14}$ Thus, following the Vienna Convention approach, the Preamble has been used as an important tool for purposes of interpretation of the ICSID Convention.

Such use of the Preamble is also in accordance with the case law of the International Court of Justice (hereinafter, the 'ICJ'). Indeed, the ICJ has ruled that in order to interpret the provisions of a treaty, it is necessary to take into account its stated purposes contained in the preamble. ${ }^{15}$ Faithful to the Vienna Convention approach, the ICJ explicitly recognized the interpretative value of preambles under public international law and refused to go beyond the scope of the declared purpose and object of a treaty. ${ }^{16}$

10 Dominique Carreau and Fabrizio Marrella, 'Chapter IV, Treaties between States' in Droit International de l'investissement (Pedone 2014, 2nd edn, 2017), para. 16.

11 Hulme (n 8) 1285.

12 Vienna Convention on the Law of Treaties (n 9).

13 Phoenix Action, Ltd. v. Czech Republic, ICSID Case No. ARB/06/5, Award (15 April 2009), para. 76.

14 Bayindir Insaat Turizm Ticaret Ve Sanayi A.S. v. Islamic Republic of Pakistan, ICSID Case No. ARB/03/29, Decision on Jurisdiction (14 November 2005), para. 96.

15 Case concerning rights of nationals of the United States of America in Morocco, France v. United States of America, Judgment (27 August 1952), ICJ Rec. 1952, 196.

16 ibid. 
0.16 In this vein, arbitral tribunals have taken full advantage of preambles as a tool to justify their interpretation of certain clauses contained in bilateral investment treaties (BIT). For instance, in the Urbaser case, the arbitral tribunal interpreted the Preamble as indicating that the rights and obligations of both arbitrating parties under the BIT should be assessed in a balanced manner and not as imposing unilateral obligations on the State. ${ }^{17}$ This interpretation was also followed in the Ambiente Ufficio v. Argentine Republic case. ${ }^{18}$

0.17 It has been observed that " $\mathrm{t}$ ] he preamble to a treaty (which does not and should not have direct operative force) has effect as indicating the general purposes and spirit of the treaty, in the light of which the interpretation to be given to particular provisions may be considered'. ${ }^{19}$

0.18 Nevertheless, the use of some preambles has gone beyond the simple interpretative function, and some tribunals have provided a normative function to such text. Thus, it is necessary to adopt an in concreto approach. Under such approach, the extent of the normative value for each preamble will emerge from its terms, from how it is actually written. This is why some scholars advocate a more precise study of each preamble in order to determine the extent to which it will bind the parties to the treaty.

0.19 Evaluating the normative value of one preamble requires therefore taking a very singular approach. Paradoxically, the Preamble which serves as an instrument of interpretation, will itself be interpreted for the purpose of determining to which degree one wants to give it a normative value. Accordingly, some authors in international law deem that the normative value of a preamble to an international treaty is not predefined and shall only depend instead on the precise wording of its statements: if the drafters inserted provisions which appear as obligations, then the preamble itself shall be considered as having a proper normative value. ${ }^{20}$

17 Urbaser S.A. and Consorcio de Aguas Bilbao Biskaia, Bilbao Biskaia Ur Partzuergoa v. Argentine Republic, ICSID Case No. $\mathrm{ARB} / 07 / 26$, Decision on Jurisdiction (19 December 2012), para. 53 (invoked to interpret the buffer time period for bringing a claim under the Argentina-Spain BIT).

18 Ambiente Ufficio S.P.A. and others (formerly Giordano Alpi and others) v. Argentine Republic, ICSID Case No. ARB/08/9, Dissenting Opinion of Santiago Torres Bernardez (2 May 2013), paras. 234-35 (criticizing the 'subjectivist unilateral vision of the Majority Decision' by referring to the Report of the Executive Directors, in which it was stated that 'the provisions of the Convention maintain a careful balance between the interest of investors and those of host States').

19 Gerald Gray Fitzmaurice, 'The Law and Procedure of the International Court of Justice: Treaty Interpretation and Certain Other Treaty Points'(1951) 1 British Yearbook of International Law, para. 4.

20 Julian Fernandez and Xavier Pacreau, Statute of Rome of the International Criminal Court, Commentary on each Article (L. Maze, Pedone, 2012). 
In this sense, Julian Fernandez and Xavier Pacreau, basing their analysis on the preamble of the Statute of Rome, which established the International Criminal Court, reasoned as follows:

Many believe that a preamble has no normative value. This belief is incorrect. It depends on the content and wording of the preamble. The preamble of the ICC Statute contains provisions that are sometimes optional and sometimes normative. Of these, one cannot overemphasize the paragraph $4-6$ which provide that States must fight against impunity for perpetrators of the most serious crimes $\left[\ldots .{ }^{21}\right.$

If one applies this approach to the Preamble, it appears that the drafters of the Convention intended from the outset to formulate some obligations to its signatories. In fact, some provisions of the Preamble are phrased in such way as to establish binding directives.

Indeed, the Preamble consists of seven paragraphs, four of which seem to impose a certain course of action:

[...] Attaching particular importance to the availability of facilities for international conciliation or arbitration to which Contracting States and nationals of other Contracting States may submit such disputes if they so desire;

Desiring to establish such facilities under the auspices of the International Bank for Reconstruction and Development;

Recognizing that mutual consent by the parties to submit such disputes to conciliation or to arbitration through such facilities constitutes a binding agreement which requires in particular that due consideration be given to any recommendation of conciliators, and that any arbitral award be complied with;

Declaring that no Contracting State shall by the mere fact of its ratification, acceptance or approval of this Convention and without its consent be deemed to be under any obligation to submit any particular dispute to conciliation or arbitration $[\ldots]^{22}$

The accuracy of the terms used in the Preamble from the very first sentences indicates that the drafters already intended to set out rules that were meant to be developed in the core of the treaty. For instance, 'nationals of other Contracting States' is used twice in the Preamble. Moreover, the expression 'ratification, acceptance or approval' reflects a certain degree of precision that one can find in an actual binding contract.

All these clues lead to the conclusion that, according to the above theory, the Preamble appears to have a degree of normative value, meaning that it was intended to bind the parties to the Convention to a certain degree.

21 ibid. para. 14.

22 Emphasis added. 
0.25 The normative value of the Preamble is further reflected in its use by arbitral tribunals in order to overcome the lack of definitions of certain key concepts contained in the Convention, ranging from the notion of 'consent to arbitration' to 'foreign investor'.

\title{
3. THE NOTION OF 'CONSENT TO ARBITRATION': A LIMITATION OF THE CENTRE'S JURISDICTION AND AN ILLUSTRATION OF THE PREAMBLE'S NORMATIVE VALUE
}

0.26 With the creation of the ICSID system, private investors became real actors in the international legal system and were able to act directly against a State without the need to rest upon their own State's diplomatic protection. However, this new power was offset by the requirement of State consent under the Convention.

0.27 In this sense, 'for reconciling such (apparently) conflicting goals, the ICSID Convention did not break away with consent. Not at all. It rather seemed to strongly multiply the layers of consent needed, in what eventually appeared as a Matryoshka system of overlapping and interlocking consensual mechanisms'. ${ }^{23}$

0.28 The last two paragraphs of the Preamble (Recitals 6 and 7) stress the value given to the notion of consent in the ICSID Convention:

\begin{abstract}
Recognizing that mutual consent by the parties to submit such disputes to conciliation or to arbitration through such facilities constitutes a binding agreement [...] [emphasis added] and 'Declaring that no Contracting State shall by the mere fact of its ratification, acceptance or approval of this Convention and without its consent be deemed to be under any obligation to submit any particular dispute to conciliation or arbitration [emphasis added].
\end{abstract}

0.29 Therefore, the Preamble introduces rules pertaining to the jurisdiction of the Centre, and comprises a normative content. ${ }^{24}$ It is clear that the drafters of the ICSID Convention intended to limit the recourse to the Centre to States that had expressly consented to it. As commented in the Preamble of the Preliminary Draft of the Convention dated 15 October 1963, 'paragraphs 4 and 6 [respectively equivalent to Recitals 4 and 7 of the final version of the Preamble] emphasize that recourse to the Centre is purely optional'. 25

23 Horia Ciurtin, 'Chapter 2: Paradoxes of (Sovereign) Consent: On the Uses and Abuses of a Notion in International Investment Law', in Crina Baltag (ed.), ICSID Convention after 50 Years: Unsettled Issues (Kluwer Law International 2016), 48.

24 Roberto Castro de Figueiredo, 'Chapter 3: The Notion of Investment and Economic Development under the ICSID Convention', in Crina Baltag (ed.), ICSID Convention after 50 Years: Unsettled Issues (Kluwer Law International 2016), 112.

25 History of the ICSID Convention, Vol. II-1, pp. 135, 188. 
The debates and negotiations surrounding the drafting of the Convention reflect the desire from different State representatives that additional requirements be inserted in the Preamble in an effort to clearly delineate the jurisdiction of the Centre. Indeed, the 'transformation of subsequent versions of the ICSID Convention reflected the preoccupation of sovereign States in maintaining their control upon the entire process and not be "forced" by the "good offices" - and symbolic power - of the Secretariat to consent to a procedure they would have not otherwise'. ${ }^{26}$

Thus, the Preamble is additional proof of the delimitation of the Centre's jurisdiction, and that States' consent is at the nub of the ICSID mechanism. However, 'the Convention does not qualify this consent in any manner. Apart from being "mutual" and "in writing", no other requirements are attached to the actual manifestation of consent, leaving the door open to any possibility of expressing it'. ${ }^{27}$ Naturally, further questions arise as to the form and scope of such consent.

\section{A. The form of the State's consent}

Although this goes without saying, one of the fundamental principles of international law is State consent. The same applies in international arbitration, where 'the consent of the parties to the dispute plays a paramount role'. ${ }^{28}$ This, in a more idyllic way, means that '[1]ike consummated romance, arbitration rests on consent'. ${ }^{29}$

In this vein, the arbitral tribunal in Tidewater $v$. Venezuela considered that 'a fundamental tenet of the ICSID Convention is that "no Contracting State shall by the mere fact of its ratification, acceptance or approval of this Convention and without its consent be deemed to be under any obligation to submit any particular dispute to conciliation or arbitration"”. ${ }^{30}$

It follows from the above that under the ICSID Convention, consent must be established, and not inferred. In this regard, a State's 'consent to ICSID arbitration can be identified in a treaty, in a national investment law or in a contract. Nevertheless, an idea of implicit consent is not admissible in the ICSID system. Whatever the instrument in which consent to ICSID arbitration is embodied, consent must be given in

26 Horia Ciurtin (n 23), 47.

27 ibid. 50.

28 Ambiente Ufficio (n 18), para. 106; Ambatielos Case, Greece v. United Kingdom ('Ambatielos') ICJ Reports 1953.

29 William W. Park, 'Non-Signatories and International Contracts: An Arbitrator's Dilemma' in Multiple Party Actions in International Arbitration: Consent, Procedure and Enforcement (OUP 2009), 3, relying on Horia Ciurtin (n 23) 48.

30 Tidewater Investment SRL, Tidewater Caribe, C.A. et al. v. Bolivarian Republic of Venezuela, ICSID Case No. ARB/10/5, Decision on Jurisdiction (8 February 2013), para. 131. 
writing'. ${ }^{31}$ As some have noted, '[ $t$ ] he certainty of written consent preserves the possibility of States and their representatives to separate their international bargaining positions from "serious" offers meant to create rights'. ${ }^{22}$

0.35 In this respect, the Preamble has to be read in conjunction with Article 25(1) of the Convention, which states inter alia that the parties to the dispute must consent in writing to submit their dispute to the Centre and that once this has been done, no party may withdraw its consent unilaterally. And so, it appears that the Preamble serves as an introduction to the rule of Article 25(1), thereby comforting the idea that the Preamble also serves as an interpretative instrument. ${ }^{33}$

0.36 Nonetheless, the Preamble also sets out the specific principle that the consent expressed through the ratification of the Convention is not the consent required by the Convention for bringing a claim before the Centre. Indeed, the latter requires 'a separate declaration by means of a treaty or other acts making such consent unequivocally clear'. ${ }^{34}$ In other words, the ratification of the Convention serves only to make the State party to it and does not automatically grant jurisdiction to an ICSID tribunal to resolve a dispute against that State. ${ }^{35}$

0.37 As expressed in the first paragraph of the Preamble, the ICSID arbitration mechanism was built in the interest of both investors and States: economic development is linked to the protection of private investments. Thus, although at a first glance, one may think that Recital 6 of the Preamble aims to settle a balance between the two parties (the investor and the State) by requiring a mutual consent, the Preamble illustrates in fact the political will of the drafters to create an asymmetrical system, composed of different layers of consent requirements under the sole control of States. ${ }^{36}$

0.38 In this sense, the Preamble marks the first step in the numerous filters governing the access to the ICSID arbitral process ${ }^{37}$ Indeed, the two last paragraphs of the Preamble serve each other in a hermeneutic manner and cannot be understood without the other:

Garanti Koza LLP v. Turkmenistan, ICSID Case No. ARB/11/20, Dissenting Opinion of Laurence Boisson de Chazournes (3 July 2013), para. 47.

32 Horia Ciurtin (n 23) 50

33 See Commentary on Article 25(1) in this book at pp. 102-62.

34 Sempra Energy International v. Argentine Republic, ICSID Case No. ARB/02/16, Decision on Objections to Jurisdiction (11 May 2005), para. 139.

35 Andrea M. Steingruber, 'Notion, Nature and Extent of Consent in International Arbitration'(PhD Thesis, Queen Mary University of London 2009), 267.

36 Horia Ciurtin (n 23) 48.

37 ibid.: 'Therefore, the first step in analysing the dilemmas of sovereign consent in the ICSID regime is to begin with the Washington Convention's preamble. Such introductory parts to international covenants do not simply serve a declaratory and rhetorical purpose. Quite the opposite, preambles such as this actually reveal the underlying context and the 
[t]he first one of them shows in a non-equivocal manner that once a 'mutual consent' of the parties to commence arbitral proceedings has been met, they are to comply with any outcome. Such an obligation is, in reality, just another consequence of consent and of the State's possibility to act freely and bind itself. Pacta sunt servanda is a corollary of consent. The other quoted sentence of the Preamble portrays the previous one - and its implicit seriousness - in less stern terms: such an obligation cannot merely arise by signing the Convention. Its framework remains only virtual, latent until another layer of consent is added, in a concrete case (or a set of pre-defined cases). ${ }^{38}$

The Preamble also allowed arbitral tribunals to set out the principle according to which the investor bears the burden of proof with regards to the State's consent, and that a strict threshold exists for proving such consent. It also rests upon the investor to obtain the consent of the State, and not the other way around.

In this regard, Recital 7 of the Preamble has been particularly relevant regarding the backlash against investment arbitration in Latin America, the denunciation by some States (Ecuador, Venezuela, Bolivia) of the ICSID Convention, ${ }^{39}$ jointly with their declared intent to equally denounce their BITs. The Venezuelan cases ${ }^{40}$ are particularly illustrative of this issue. In such cases, the investors attempted to fend off the State's claim that it had withdrawn its offer to arbitrate by denouncing the ICSID Convention.

The arbitral decisions in these cases defined a threshold for a finding that the State gave its consent in an instrument other than a BIT or an investment contract, in particular in a domestic piece of legislation. The tribunals focused on the interpretation of Article 22 of Venezuela's investment law, ${ }^{41}$ which reads as follows:

will of the parties at the moment of signing the treaty. Moreover, as stated in doctrine, "[s]ometimes ... the preamble contains what are essentially political statements", not playing just an ancillary or introductory role in the context of the treaty, but illustrative of the sovereign intentions of parties and the scope of their expressed consent when entering into the convention.'

38 ibid. at 49.

39 J. Fouret, 'Denunciation of the Washington Convention and Non-Contractual Investment Arbitration: "Manufacturing Consent” to ICSID Arbitration?' (2008) 25(1) Journal of International Arbitration 71.

40 Mobil Corporation, Venezuela Holdings, B.V., Mobil Cerro Negro Holding, Ltd., Mobil Venezolana de Petróleos Holdings, Inc., Mobil Cerro Negro, Ltd, and Mobil Venezolana de Petróleos, Inc. v. Bolivarian Republic of Venezuela, ICSID Case No. ARB/07/27, Decision on Jurisdiction (10 June 2010), para. 140; Cemex Caracas Investments B.V. and Cemex Caracas II Investments B.V. v. Bolivarian Republic of Venezuela, ICSID Case No. ARB/08/15, Decision on Jurisdiction (30 December 2010), para. 138; Brandes Investment Partners, LP v. Bolivarian Republic of Venezuela, ICSID Case No. ARB/08/3, Award (2 August 2011), para. 118; Tidewater Investment (n 30) para. 141; OPIC Karimun Corporation v. Bolivarian Republic of Venezuela, ICSID Case No. ARB/10/14, Award (28 May 2013), para. 181(a); ConocoPhillips Petrozuata B.V. and others v. Bolivarian Republic of Venezuela, ICSID Case No. ARB/07/30, Decision on Jurisdiction and Merits (3 September 2013), para. 261; Venoklim Holding B.V. v. Bolivarian Republic of Venezuela, ICSID Case No. ARB/12/22, Award (3 April 2015), para. 112.

41 Mobil Corporation (n 40) para. 68. 
Disputes arising between an international investor whose country of origin has in effect with Venezuela a treaty or agreement on the promotion and protection of investments, or disputes to which are applicable the provisions of the Convention Establishing the Multilateral Investment Guarantee Agency (OMGI-MIGA) or the Convention on the Settlement of Investment Disputes between States and Nationals of Other States (ICSID), shall be submitted to international arbitration according to the terms of the respective treaty or agreement, if it so provides, without prejudice to the possibility of making use, when appropriate, of the dispute resolution means provided for under the Venezuelan legislation in effect.

0.42 The arbitral tribunals referred to the Preamble of the Convention to clarify the ambiguous drafting of this clause and to conclude that Venezuela did not consent to arbitration with this provision. The rationale was that it cannot be inferred from Article 22, read in light of Recital 7 of the Preamble, that Venezuela gave a general consent to arbitration. ${ }^{42}$

0.43 As another illustration, in the ConocoPhillips case, the arbitral tribunal deemed that:

[...] those four words - if it [the treaty or agreement] so provides [should it so provide] - present the essential issue to be determined. They do state a condition - as indeed the Claimants' expert on Venezuelan law accepted. In the Tribunal's opinion, that condition has not been satisfied. It is not enough, as the Claimants contend, that the ICSID Convention provides for international arbitration. That treaty must itself manifest Venezuela's consent to arbitration; but that treaty does not do that, as its Article 25 and preamble make clear. The ordinary meaning of the terms of Article 22, and especially of the condition, leads the Tribunal to the conclusion that Venezuela does not by that means consent to international arbitration under the ICSID Convention. Other considerations support that conclusion. ${ }^{43}$

0.44 Although it seems that this provision in particular does not constitute consent to ICSID jurisdiction on the part of Venezuela, other States that contemplate denouncing their BITs or the ICSID Convention might face similar claims on the basis of their own legislation.

\section{B. The scope of the State's written consent}

0.45 Once a State has given its written consent to arbitration, such consent is deemed to cover multiple forms of arbitration. This has been particularly the case regarding mass claims arising out of sovereign debt defaults. 
With regards to the scope of consent, the tribunal in the landmark case of Abaclat v. Ar-

gentin $a^{44}$ held that Argentina's consent to ICSID arbitration covered claims presented by multiple claimants in a single proceeding.

Nevertheless, in that case, Professor Georges Abi-Saab issued a dissenting opinion based largely on the Preamble of the Convention. He considered that the Preamble demonstrates that the drafters did not intend to create an 'open-ended standing court of general jurisdiction', ${ }^{45}$ and that the 'argument of the majority award based on the unforeseeability of collective actions at the time of drafting the Convention, paradoxically bears in favour of interpreting the silence of the ICSID Convention as not extending to cover such an extra-ordinary type of judicial activity as representative proceedings or class actions'. ${ }^{46}$

However, it is interesting to note that the latter view was not subsequently followed. For instance, the arbitral tribunal in the Ambiente Ufficio case found that it [was] evident that multi-party arbitration is a generally accepted practice in ICSID arbitration', and that 'the institution of multi-party proceedings therefore does not require any consent on the part of the respondent Government beyond the general requirements of consent to arbitration'. ${ }^{47}$

Sovereign debt disputes remain a major issue worldwide, particularly in investment arbitration. Since no ICSID rule addresses this issue, arbitral tribunals will be bound to decide on whether or not they should receive mass claims based on a State's general consent to arbitration. In this regard, the Preamble can be revealing.

In the same way that the Preamble seems to have enlightened practitioners of international arbitration on the notion of State consent to ICSID arbitration, the definition of 'investment' under the Convention has been somewhat filled in with the use of the Preamble.

\section{THE NOTION OF'INVESTMENT': A CONTROVERSIAL USE OF THE PREAMBLE}

As explained in the First Preliminary Draft of the Convention:

44 Abaclat and Others v. Argentine Republic, formerly Giovanna a Beccara and Others v. Argentine Republic, ICSID Case No. ARB/07/5 (4 August 2011), para. 500.

45 Abaclat and Others v. Argentine Republic, formerly Giovanna a Beccara and Others v. Argentine Republic, ICSID Case No. ARB/07/5, Dissenting Opinion to Decision on Jurisdiction and Admissibility (4 August 2011), para. 165.

46 ibid. para. 166.

47 Ambiente Ufficio (n 80) para. 141. 
No detailed definition of the category of disputes in respect of which the facilities of the Center would be available has been included in the Convention. Instead, the general understanding reflected in the Preamble, the use of the term investment dispute, and the requirement that the dispute be of a legal character as distinct from political, economic or purely commercial disputes, were thought adequate to limit the scope of the Convention in this regard. ${ }^{48}$

0.52 Arbitral tribunals are regularly faced with questions regarding the scope of the ICSID Convention. The Preamble has played an important role in answering such questions, in particular with respect to the identification of a protected investment under the Convention.

0.53 The existence of an 'investment' is indeed a prerequisite to establish the jurisdiction of the Centre. Article 25(1) of the Convention provides:

The jurisdiction of the Centre shall extend to any legal dispute arising directly out of an investment, between a Contracting State (or any constituent subdivision or agency of a Contracting State designated to the Centre by that State) and a national of another Contracting State, which the parties to the dispute consent in writing to submit to the Centre. $^{49}$

0.54 However, the drafters of the Convention left undefined the term 'investment'. This lack of definition has long been understood as aiming at avoiding undesirable limitations on the Centre's jurisdiction and as giving the parties greater discretion in this regard. ${ }^{50}$ Nonetheless, as explained by Aron Broches, such 'discretion is not unlimited and cannot be exercised to the point of being clearly inconsistent with the purposes of the Convention'. ${ }^{51}$ Yet, the issue was that the broad wording of the Convention enabled claims to be filed regarding transactions that could not reasonably qualify as investments.

0.55 In attempting to delineate the Convention's scope ratione materiae, some tribunals have taken a teleological approach to the interpretation of the ICSID Convention and used the Preamble to construe the 'investment' requirement in a way that expands or restricts the jurisdiction of the Centre, conferring once again a normative value to the Preamble.

48 History of the ICSID Convention, Vol. II-1, p. 149.

49 See Commentary on Article 25(1) (emphasis added) at pp. 102-62.

50 Castro de Figueiredo (n 24) 77.

51 Aron Broches, 'The Convention on the Settlement of Investment Disputes between States and Nationals of Other States' (1972) 136 Recueil des Cours 331-62. 


\section{A. The role of the Preamble in defining an investment in the light of the object and purpose of the ICSID Convention}

The Preamble of the ICSID Convention has been used on various occasions, namely in order to interpret the notion of 'investment' in light of the Convention's main objectives and purposes, and in particular the economic development of host States through the flow of private international investment.

As rightly pointed out by an author, "[e]ven if Article 25 of the ICSID Convention does not provide a definition or further details when it mentions the term "investment," the concept cannot be properly understood if isolated from the preamble of the Convention, which links the notion of investment under the Convention to that of economic development of capital-importing states' ${ }^{52}$

In this regard, the arbitral tribunal in MHS v. Malaysia held that:

Taking a teleological approach to the interpretation of the ICSID Convention, a tribunal ought to interpret the word 'investment' so as to encourage, facilitate and to promote cross-border economic cooperation and development. Support for such an approach can be found in the Preamble to the ICSID Convention [... A Accordingly, the term 'investment' should be interpreted as an activity which promotes some form of positive economic development for the host State. ${ }^{53}$

The first decision to refer to the Preamble in an attempt to define an investment for ICSID purposes was CSOB v. Slovakia, where the tribunal stated:

Support for a liberal interpretation of the question whether a particular transaction constitutes an investment is also found in the first paragraph of the Preamble to the Convention, which declares that 'the Contracting states [are] considering the need for international cooperation for economic development, and the role of private international investment therein'. This language permits an inference that an international transaction which contributes to cooperation designed to promote the economic development of a Contracting State may be deemed to be an investment as that term is understood in the Convention. ${ }^{54}$

Thus, the tribunal considered that an international economic activity that contributes

52 Dalia Hussein, 'Contribution to the Host State Development: A Marginalised Criterion?' (2015) 2(2) BCDR International Arbitration Review 292.

53 Malaysian Historical Salvors SDN, BHD v. The Government of Malaysia, ICSID Case No. ARB/05/10, Award on Jurisdiction (17 May 2007), para. 66.

54 Ceskoslovenska Obchodni Banka, A.S. v. The Slovak Republic, ICSID Case No. ARB/97/4, Decision of the Tribunal on Objections to Jurisdiction (24 May 1999), para. 64. 
to the economic development of the host State may be presumed to be an investment under the Convention based on the wording of the Preamble.

0.61 Similarly, the tribunal in the Fedax v. Venezuela case held that: " $\mathrm{t}]$ he basic features of an investment have been described as involving a certain duration, a certain regularity of profit and return, assumption of risk, a substantial commitment and a significance for the host State's development'. ${ }^{55}$

0.62 This notion of 'economic development' of the host State, described as a mere feature of an investment in the Fedax case, was eventually transformed into a criterion for the identification of an investment under the Convention. ${ }^{56}$ While previous decisions had settled on three criteria in order to identify an investment, the Salini tribunal decided to add a fourth criterion, directly drawn from the Preamble: the contribution to the host State's economic development. ${ }^{57}$ Thus, under the Salini test, an operation may be deemed an investment under Article 25 of the ICSID Convention only if it involves: (i) a contribution; (ii) a certain duration of performance; (iii) a participation in the risks of the transaction; and (iv) a contribution to the economic development of the host State.

0.63 Therefore, the notion of 'economic development of the host State' was used to depart from the ordinary notion of 'investment': although an activity could be considered an investment in its ordinary meaning, the lack of contribution to the economic development of the host State would have the effect of excluding such activity from the Centre's jurisdiction.

0.64 This definition of an investment for ICSID purposes, different from the one in CSOB v. Slovakia, became, and still remains, a very controversial issue.

0.65 However, many arbitral tribunals have 'firmly accepted'58 the Salini test. It was used in numerous subsequent cases, although sometimes in a slightly modified version (requiring, for example, the economic development to be significant, ${ }^{59}$ or dropping the requirement that the development be economic in nature ${ }^{60}$ ).

Fedax N.V.v. The Republic of Venezuela, ICSID Case No.ARB/96/3, Decision of the Tribunal on Objections to Jurisdiction (11 July 1997), para. 43.

56 Salini Costruttori S.p.A. and Italstrade S.p.A. v. Kingdom of Morocco, ICSID Case No. ARB/00/4, Decision on Jurisdiction (23 July 2001), para. 52.

57 ibid.

58 Rudolf Dolzer and Christoph Schreuer, Principles of International Investment Law (2nd edn, OUP 2012), 67.

59 Joy Mining v. Machinery Limited v. Arab Republic of Egypt, ICSID Case No. ARB/03/11, Award on Jurisdiction (6 August 2004), para. 53; Bayindir Insaat (n 14) para. 131.

60 Saipem S.p.A. v. The People's Republic of Bangladesh, ICSID Case No. ARB/05/07, Decision on Jurisdiction and Recommendation on Provisional Measures (21 March 2007), para. 99. 
Even tribunals that have refused to consider the elements of the Salini test to be man-

datory have nevertheless recognized them as 'benchmarks' ${ }^{61}$ that 'may still prove useful, provided that they are treated as guidelines and that they are applied in conjunction and in a flexible manner'. ${ }^{62}$

However, this interpretation of the Preamble as limiting the scope of jurisdiction of ICSID tribunals has been largely criticized. ${ }^{63}$

\section{B. Critical responses to the interpretation of the Preamble as restricting the ICSID scope of jurisdiction}

By defining the 'investment' requirement so as to give effect to the object and purpose of the Convention, the Salini case adopted a teleological approach to interpreting the Preamble. This interpretation has been largely criticized as being excessive and unnecessarily restricting the jurisdiction of ICSID tribunals.

According to some authors, such interpretation is inconsistent with the general rule of treaty interpretation set forth in Article 31 of the Vienna Convention, which prefers a textual approach. As an illustration, in its article, Roberto Castro de Figueiredo considers that the mere reference to the 'economic development' of the host State is insufficient to expand or restrict the jurisdiction of the Centre. ${ }^{64}$

Similarly, Christoph Schreuer has deemed that:

[t]he reference in the Convention's Preamble indicates that economic development is among the Convention's object and purpose. This would support the proposition that an international transaction that is designed to promote the host State's development enjoys the presumption of being an investment. But it does not follow that an activity that does not obviously contribute to economic development must be excluded from the Convention's protection. ${ }^{65}$

Many arbitral tribunals have followed this line of reasoning and thus rejected a strict application of the Salini test. ${ }^{66}$ For example, in the Saba Fakes case, the tribunal held that:

61 RSM Production Corporation v. Grenada, ICSID Case No. ARB/05/14, Award (13 March 2009), paras 241-44.

62 Ambiente Ufficio (n 18) para. 481.

63 Castro de Figueiredo (n 24) 98.

64 ibid. 77.

65 Christoph H. Schreuer and others, 'Article 25' in The ICSID Convention: A Commentary (2nd edn, CUP 2009), para. 173.

66 Biwater Gauff(Tanzania) Ltd v. United Republic of Tanzania, ICSID Case No. ARB/05/22, Award (24 July 2008), para. 
The Tribunal is not convinced, on the other hand, that a contribution to the host State's economic development constitutes a criterion of an investment within the framework of the ICSID Convention. Those tribunals that have considered this element as a separate requirement for the definition of an investment, such as the Salini Tribunal, have mainly relied on the preamble to the ICSID Convention to support their conclusions. The present Tribunal observes that while the preamble refers to the 'need for international cooperation for economic development', it would be excessive to attribute to this reference a meaning and function that is not obviously apparent from its wording. ${ }^{67}$

0.72 Indeed, the fact that the Preamble mentions the economic development of the host State may be seen as a simple desire to underline that the dispute resolution mechanism of the Centre was built in the interests of both the investors and the host States in a necessary balanced exercise. In this sense, the economic development of the host State is rather a desirable consequence of an investment rather than a mandatory requirement. This idea was highlighted by the arbitral tribunal in the Amco v. Indonesia case, ${ }^{68}$ and later confirmed by the tribunal in Pey Casado. ${ }^{69}$

0.73 Similarly, arbitral tribunals have considered the contribution to the development of the host State as being induced by the existence of the other criteria. ${ }^{70}$ In this sense, as rightly summarized by an author:

While some tribunals have explicitly considered contribution to the host state development to be an essential element of an investment, others considered that it was not necessary for the contribution to host state development to be a distinct element; it was implied by the other three criteria. ${ }^{71}$

0.74 Finally, some tribunals have avoided the issue altogether by refusing to decide whether the fourth prong of the Salini test should be decisive in the identification of an

312: 'In the Tribunal's view, there is no basis for a rote, or overly strict, application of the five Salini criteria in every case. These criteria are not fixed or mandatory as a matter of law. They do not appear in the ICSID Convention.'

67 Saba Fakes v. Republic of Turkey, ICSID Case No. ARB/07/20, Award (14 July 2010), para. 111.

68 Amco Asia Corporation and others v. Republic of Indonesia, ICSID Case No. ARB/81/1, Decision on Jurisdiction (25 September 1983), para. 249.

69 Victor Pey Casado and President Allende Foundation v. Republic of Chile, ICSID Case No. ARB/98/2, Award (8 May 2008), para. 232: 'It is true that the preamble of the ICSID Convention mentions the contribution to the economic development of the host State. Nevertheless, such reference is a consequence and not a requirement of the investment: protecting investments, the Convention favors the development of the host State. This does not mean that the development of the host State is a constitutive element of the notion of investment.'

70 Bayindir Insaat Turizm Ticaret Ve Sanayi A.S. v. Islamic Republic of Pakistan, ICSID Case No. ARB/03/29, Award (29 August 2009), para. 137; Consortium Groupement L.E.S.I.- DIPENTA v. République algérienne démocratique et populaire, ICSID Case No. ARB/03/08, Award (10 January 2005), para. 13.

71 Laurens J. E. Timmer, “The Meaning of "Investment” as a Requirement for Jurisdiction Ratione Materiae of the ICSID Centre' (2012) 29(4) Journal of International Arbitration 367. 
investment, holding instead that this condition would be satisfied in the case at hand anyway. ${ }^{72}$

This commentary takes the approach that the fourth criterion of the Salini test is not necessarily accurate. The problem it raises stems from its subjectivity. How can one really decide whether or not a foreign investment contributes to the economic development of a country? Depending on the sectors of activity and also on the individual points of view of each arbitrator, the answer will vary. As rightly pointed out, this criterion 'can often be a matter of appreciation and can generate a wide spectrum of reasonable opinions' ${ }^{73}$

In addition, for some authors and tribunals, there should be no need to inquire as to the definition of an investment under anything else than the definition provided under the applicable investment treaty. This more broad approach would allow the parties, and later the arbitral tribunal, to adapt to the circumstances of each case. ${ }^{74}$ Such an approach was indeed used in several cases. ${ }^{75}$

Interestingly, Gerald Fitzmaurice has strongly criticized the teleological interpretation of treaties. Faithful to the approach of the Vienna Convention, he seems to condemn any method of interpretation that resorts to external circumstances or considerations, which are likely to interfere with the primary wording of the text reflecting the intentions of the parties:

The intentions of the framers of a treaty, as they emerged from the discussions or negotiations preceding its conclusion, must be presumed to have been expressed in the treaty itself, and are therefore to be sought primarily in the actual text, and not in any extraneous source. Furthermore, treaties must be interpreted as they stand, and subject to the limitations inherent in the fact that they only contain so many articles, phrases, and words. The intentions or presumed intentions of the framers cannot be invoked to fill in gaps, or import into the treaty something of which is apparently plain, or to give them a sense different from that which they possess according to their normal and natural meaning. In short, the attitude of the Court to a text is not, primarily, to ask itself what was this text intended to mean (still less of course what ought it to mean, or to be made to mean), but what does it in fact mean on its actual wording? ?6 $^{76}$

72 ibid.

73 Castro de Figueiredo (n 24) 98-99.

74 Emmanuel Gaillard and Yas Banifatemi, 'Chapter 8: The Long March Towards a Jurisprudence Constante on the Notion of Investment' in Meg N. Kinnear, Geraldine R. Fischer, et al. (eds), Building International Investment Law: The First 50 Years of ICSID (Kluwer Law International 2015), 97, 104-10.

75 Flemingo DutyFree Shop Private Limited v. Republic of Poland, UNCITRAL, Award, 12 August 2016, para. 298; Garanti Koza (n 31) paras 294-98.

76 Fitzmaurice (n 19) 10. 
0.78 The normative value of the Preamble is therefore highly debatable and will, without a doubt, fuel further debates in the near future considering the opposing view of many tribunals and authors.

0.79 In addition to the concepts of 'consent' and 'investment', the Preamble was finally used to shed light on the jurisdiction ratione personae of ICSID arbitral tribunals, based on the interpretation of the concept of 'foreign investor'.

\section{THE NOTION OF 'FOREIGN INVESTOR': A PRUDENT INTERPRETATION OF THE PREAMBLE}

0.80 The drafters of the Convention and the Preamble had not anticipated what is nowadays' complex company structures. This issue resulted in the increase of situations not clearly addressed in the Convention and to which the ICSID tribunals had to adapt. To this end, relying on the Preamble was necessary and useful for interpretative purposes.

0.81 Contrary to the teleological interpretation that has been given to the Preamble with regard to the notion of 'investment', a much more literal approach was chosen with regards to the notion of 'foreign investor'. Nonetheless, this view is similarly not unanimous.

\section{A. The literal interpretation of the Preamble: the Tokios Tokelés case}

0.82 The Preamble addresses 'disputes [that] may arise in connection with such investment between Contracting States and nationals of other Contracting States'. The text is clear in this sense since the Convention provides for mechanisms of settlement of disputes between a State and a national of another State. It does not apply to disputes between a State and its own nationals.

0.83 Although this idea seems clear, the definition of a foreign investor may not always be as simple as that, since methods for defining a corporate nationality may greatly vary. Furthermore, investors may be attracted by the possibility of creating foreign corporations only as a means of getting access to the jurisdiction of the Centre.

0.84 In this regard, the Tokios Tokelés case raised the issue of definition and understanding of the term 'nationals of other Contracting States'. More specifically, the question was whether or not a corporation registered in Lithuania but owned by Ukrainian nationals could bring a claim against Ukraine under the Convention. ${ }^{77}$ 
Arbitral tribunals can thus choose either to: (i) 'pierc(e) the corporate veil'; ${ }^{78}$ or (ii) not to look beyond the nationality of the company since it is a distinct and independent legal entity in itself, in order to determine if its shareholders should be considered as 'foreign investors' or 'nationals of other Contracting States'. In other words, the problem revolves around a simple question: which is the relevant nationality? That of the company, or that of the shareholders?

In the absence of any explicit indication in the Preamble or in the Convention as to 0.86 how to interpret the notion of 'nationals of other Contracting States', the Tokios Tokelés tribunal gave it a very literal interpretation. The tribunal deemed it unnecessary to inquire into the ownership of the corporation, and instead only relied upon its state of incorporation to conclude that the entity should be considered as a 'national of another Contracting State', and to affirm its jurisdiction over the dispute.

This literal interpretation of the Preamble was followed in several awards, as arbitral tribunals have shown to be reluctant to pierce the corporate veil, preferring the incorporation criteria to determine the nationality of a company, over the criteria of control, which would lead to assimilate the nationality of a legal person to that of its main, majority or exclusive shareholders. ${ }^{79}$

\section{B. A plea for a more constructive approach: piercing the corporate veil based on the Preamble}

Professor Prosper Weil, Chairman of the Tokios Tokelés tribunal, disagreed with the literal interpretation adopted by the majority. He issued a dissenting opinion in which he criticized the decision for '[resting] on the assumption that the origin of the capital is not relevant and even less decisive', and considered that 'This assumption is flying in the face of the object and purpose of the ICSID Convention and system as explicitly defined both in the Preamble of the Convention and in the Report of the Executive Directors'. 80

According to Prosper Weil, the Convention only governs investments that are international by nature and the fact that the interpretation upheld by the majority could lead to an ICSID tribunal ruling on a dispute between two nationals of the same Contracting

78 Sébastien Besson, 'Chapter 8. Piercing the Corporate Veil: Back on the Right Track' in Bernard Hanotiau and Eric A. Schwartz (eds), Multiparty Arbitration, Dossiers of the ICC Institute of World Business Law, 7 (Kluwer Law International; International Chamber of Commerce (ICC) 2010), 147-59.

79 Cedric Soule, 'The ICSID Convention and Nationals of Another Contracting State that are Owned by Nationals of the Respondent State: Back to Basics' (2015) 7(48) Revista Brasileira de Arbitragem, Comitê Brasileiro de Arbitragem CBAr \& IOB 39-58.

80 Tokios Tokelés v. Ukraine, ICSID Case No. ARB/02/18, Prosper Weil Dissenting Opinion (29 April 2004), para. 6. 
State 'runs counter to the object and purpose of the whole ICSID system'. ${ }^{81}$ Indeed, the Convention initially sought to be an instrument regulating the flow of transnational private capital, disregarding any internal flows within each Contracting State.

0.90 Prosper Weil's dissenting opinion heavily relied upon the Preamble, and in particular upon the references to the existence of 'investment [s] between Contracting States and nationals of other Contracting States', and to 'the role of private international investment' (emphasis added).

0.91 Although the Tokios Tokelés decision remains largely followed by arbitral tribunals, an ICSID tribunal has recently upheld Prosper Weil's position. ${ }^{82}$

0.92 Therefore, the strict literal interpretation of the Preamble and Convention set out in the Tokios Tokelés case are not unanimous, as it has been affirmed quite bluntly by some authors that:

By refusing to 'pierce the corporate veil', the tribunals made use of a strict positivism and, consequently, parted ways with both the spirit of the BIT and the Convention. They did not merely go beyond the norm, but against it. The arbitrators disregarded the self-evident purposes for which these legal instruments were created and allowed to function, i.e., for the protection of foreign investors operating in an unfamiliar and unexpectedly volatile legal environment. ${ }^{83}$

0.93 Commenting on the over-formalistic interpretation of the Tokios Tokelés and Rompetrol v. Romania scenario, authors such as Horia Ciurtin, have openly criticized such a choice, comparing it to the opening of a 'Pandora-box' and stating:

Considering that the will of the sovereigns was to construct a notion of 'nationality' based solely on the place of incorporation, without any reference to the effective control exercised upon a company, these tribunals did not utilise other fundamental circumstances or principles of international law. As a legitimating factor, consent was once again used in order to limit the application of teleological hermeneutics, even if that meant defeating the purpose and spirit of the initially expressed consent. ${ }^{84}$

0.94 As a concluding point, it can be said that as of today it is still uncertain whether the Preamble has mainly an interpretative function or if it possesses a normative value. The same uncertainty remains as to the hermeneutics approach to be followed for its

81 ibid. para. 19.

82 Venoklim Holding B.V. v. Bolivarian Republic of Venezuela, ICSID Case No. ARB/12/22, Award (3 April 2015), para. 155.

83 Horia Ciurtin (n 23) 69.

84 ibid. at 70 . 
own interpretation. What is certain, however, is that the importance of the role of the Preamble has continuously increased during the first 50 years of existence of the Convention and the recent case law indicates that the next years should bring no changes in such a trend. The fact that the Preamble mentions some standards and principles that are the basis of most of the jurisdictional objections raised before Arbitral Tribunals is therefore intrinsically linked to such a continuous trend. 